\section{State of denial}

Scientists regularly debate hypotheses and interpretations, sometimes feverishly. But in the public sphere, a different type of dissension is spreading through media outlets and online in an unprecedented way-one that challenges basic concepts held as undeniable truths by most researchers. 'Science denialism' is the rejection of the scientific consensus, often in favor of a radical and controversial point of view. Here, we list what we see as a few of today's most vocal denialists spreading ideas that counter the consensus in health fields.

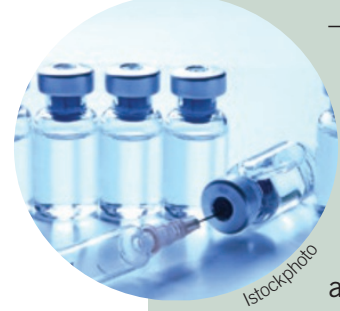

- Mark and David Geier: This father-son duo, based in Washington, DC, was among the first to publish claims that the thimerosal preservative used in certain vaccines causes autism (J. Am. Physicians Surg. 8, 6-11, 2003). Mark Geier holds a doctorate in genetics; his son, David, has a bachelor's degree in biology. Together, they promote therapies for autism including chelation, the use of chemicals to remove heavy metals from the body, and Lupron, a drug used to treat prostrate cancer and chemically castrate sex offenders. Mark Geier has testified in support of the thimerosalautism link as an expert witness at vaccine trials across the US; numerous rigorous studies, however, have dismissed this link.

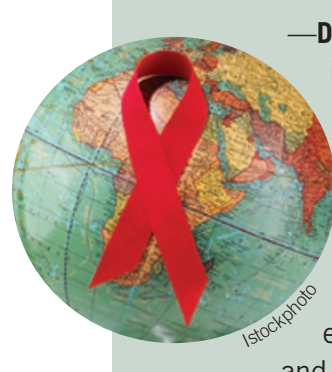

-David Rasnick: A biochemist who studied protease inhibitors in the pharmaceutical industry, Rasnick is the former president of Rethinking AIDS, an activist group that calls for the reappraisal of the 'belief' that HIV causes AIDS. Rasnick was also a member of South African president Thabo Mbeki's AIDS Advisory Panel; as part of the panel, Rasnick argued that AIDS does not exist and suggested that HIV testing be outlawed and antiretroviral drugs no longer used in the country. Although not linking their findings to Rasnick, two studies have independently estimated that more than 330,000 lives were lost in South Africa between 2000 and 2005 because of the delayed use of antiretrovirals (J. Acquir. Immune Defic. Syndr. 49, 410-415, 2008; Afr. Aff. 107, 157-176, 2008).
-Sandy Szwarc: A food editor and writer, Szwarc has rejected the idea that individuals with obesity face a heightened risk of premature death. Szwarc, a registered nurse, calls government antiobesity efforts "a grossly exaggerated and fabricated scare campaign."

On her blog "Junkfood Science," Szwarc presents the "obesity paradox,' which refers to the alleged health benefits associated with obesity, such as reports that obese individuals may have higher survival rates of coronary artery disease than their normalweight counterparts. Scientists reviewing this data, however, have suggested that this higher survival rate might be due to more aggressive treatment of people with obesity and other factors.

-Wolfgang Wodarg: Wodarg is a German physician and past head of health at the Council of Europe. Wodarg recently made headlines accusing flu drug and vaccine makers of influencing the World Health Organization (WHO) to declare swine flu a pandemic. In a recent interview, Wodarg called the H1N1 outbreak "one of the greatest medical scandals of the century," and he has made a motion that the Parliamentary Assembly of the Council of Europe begin an immediate investigation into the matter. The WHO has called allegations by people who say that it created a false pandemic as "scientifically wrong" and "irresponsible." The health agency stressed that "[t]he world is going through a real pandemic."

-Michael Fumento: Fumento is a journalist and author of several books, including The Myth of Heterosexual AIDS. He writes regularly about the promise of adult stem cells and the danger of embryonic stem cells on his blog, "Advise and Dissent," and for such outlets as the New York Post and Forbes Online. Fumento claims embryonic stem cell research is both "a dead end," fueled by a greedy lobby, and dangerous, despite evidence from animal studies suggesting its promise. He uses a picture of a tumor with teeth and hair growing from it to illustrate his point.

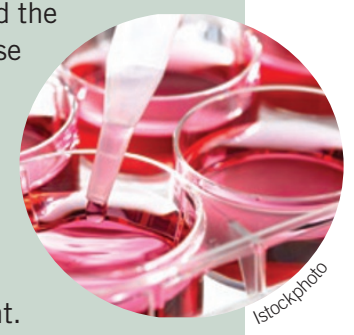

Megan Scudellari, Durham, North Carolina

\title{
A timeline of the Wakefield retraction
}

28 February Gastroenterologist Andrew Wakefield reports in The Lancet that his team has found a "genuinely new syndrome"-a link between the measles, mumps and rubella (MMR) vaccine and an increased risk of autism (Lancet 351, 637-641, 1998).
2002-2004 Numerous studies published in BMJ, The New England Journal of Medicine, The Lancet and other journals find no link between MMR and autism.

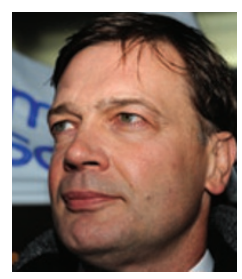

28 January The UK General Medical Council rules that Wakefield acted "dishonestly and irresponsibly," and showed "callous disregard" for the suffering of children involved in his controversial research.

\section{8

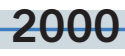

6 April Wakefield and Dublin pathologist John O'Leary present research to a US congressional committee showing that 24 of 25 autistic children tested had traces of the measles virus in their gut.

\section{4}

6 March Ten authors on the 1998 paper issue a retraction (Lancet 363, 750, 2004), and The Lancet's editor says the journal, in hindsight, should not have published the study (Lancet 363, 747-749, 2004).

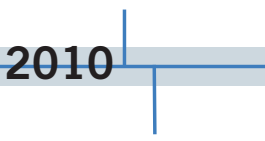

2 February The Lancet retracts Wakefield's 1998 paper, noting elements of the manuscript proved to be false (Lancet doi:10.1016/S01406736(10)60175-7, 2010). 